\title{
Students' Perception of Schoology Discussion Forum in Writing Class at Students of Uhamka
}

\author{
Burhayani $^{1}$, Kintan Kinanti $^{2}$ \\ Universitas Muhammadiyah Prof. DR. HAMKA ${ }^{1,2}$ \\ eniburhayani@yahoo.com; kinantikintan11@gmail.com
}

\begin{abstract}
The aim of this study was identified the students' perception of Schoology Discussion Forum (SDF). The aspects that were studied are cognitive, affective, and conative. This research used a qualitative method covering questionnaires and interviews as the instruments. The participants were 31 students of the Muhammadiyah Prof. DR. HAMKA University which taking Essay Writing 1 subject in class 4B. They were asked to fill the questionnaire, and six students were selected to get further interviewed by telephone. The data from questionnaire are tabulated and transcript interview were analyzed. The study revealed that $70.96 \%$ of students agree which the SDF was useful to improve their writing skill. Besides, there were $45.16 \%$ of students still nervous when using English in the discussion forum. Then, $67.74 \%$ of students were prepared themselves before the discussion begin. Therefore, this research could be used by English teachers as a reference in teaching writing skill. Not with standing, this work is an early attempt to study this area and should be followed by further research to gain more general perspective of this issue.
\end{abstract}

Keywords: Students' Perception, Discussion Forum, Schoology, Writing Class.

\section{INTRODUCTION}

Nowadays, the use of information and communication technology (ICT) has been widespread to all aspects of human life including in teaching and learning process. In technological era, there is online media that can apply in teaching-learning, which is Learning Management Systems (LMS). It is a tool for organizing distance learning by(Kerimbayev et al.,[1] . As state by Ferdianto and Dwinasih, [2]. Schoology is one of the widely used Learning Management Systems (LMS) that can use in the teaching and learning process. It is a platform that mixes social networking and LMS. It offers learning as simple and easy to use as Facebook by Wardono and Mariani [3]. According to Manning et al., [4] Schoology consists of two main context; interactive communication and academic information exchange. It means, students can interact during learning in Schoology.

Inside Schoology, there is SDF. It becomes a supporting connection indirectly for teachers and students. They can communicate with each other, like using the "homepage" on Facebook. Schmidt [5] have said that the discussion forum is a place that can be empowering for students to revise their identifications and ideas. It can be inferred that the discussion forum is the key to a distance learning process that has the power to share knowledge and ideas. Then, this study aims to determine students' perceptions of SDF, so it must be 
known that the student's perception is crucial in evaluating the success of teaching by Chen and Hoshower. [6] . Di dalam penelitian [7], [8] siswa have stated that they felt particularly helpful in using the discussion forum.

There were several researchers who has investigated about online discussion forum [9]-[11]. Alzahrani [9] has investigated students' satisfaction with using online discussion forums (ODFs). This study also examines the relationships between students' satisfaction with using ODFs and student demographics with their experience with ICT \& online education. This study has 2171 students from four universities in Saudi Arabia using an online survey. The result of this study indicates that students are satisfied with using ODFs in their learning. It also has positive relationships with students' satisfaction and using ODFs. In the same period, Alzahrani [10] investigated the effect on student learning of Online Discussion Forums. This study was carried out at a university in the western region of Saudi Arabia. The researcher used a quasi-experimental method for this study. There are two categories to be a sample. The first group is the group of experiments and the second group is the group of control groups. All participants were 135 students who studied special education, while three students from an experimental group learned Quranic. There are 67 participants in the study group and 71 in the control group. This study found that ODF's use makes students more competitive, particularly students who are actively involved in ODF. That is because OF encourages students to engage through social and collaborative work. Then, Ebrahimi et al., [11] examined Student perceptions of effective discussion in online forums use a case study of preservice teachers. This study reports on a mixed-method. This study explored the perceptions of 32 Iranian preservice teachers participating in asynchronous online discussion forums during 7-week online introductory courses of the corpus. Information was gathered through a questionnaire, discussion forum, and semi-structured online text-based interviews. They found that the participants showed positive in their attitudes, beliefs, and evaluations in the data analysis part. On the other side, they hesitate to express their feelings, answer the questions of peers and criticize others' opinions. Instead of developing social relationships, participants feel that online discussion should bring about meaningful, relevant, and useful learning outcomes and assist them with course subjects. These results can assist in postgraduate education online instructors to manage effective online communication practices.

\section{METHODS}

\subsection{Research Design}

Since this research explores students' perceptions of the Discussion Forum of Schoology for writing class, the researchers used qualitative research. Therefore, the researchers used a survey method to collect data. Survey research can be called descriptive research.

\subsection{The Setting of the Study}

This study was carried out from February to July 2020 at the Department of English Education of HAMKA University, located in East Jakarta.

\subsection{Sample of the Study}

The sample collection was based on purposive sampling, which the researchers chose for a class that used discussion forums in writing learning. Then class 4B with the Essay Writing 1 course was picked as the sample. In this class, it has 31 students who fill questionnaire and 6 students who interviewed by the researchers.

\subsection{The Research Instruments}

The selection of suitable instruments in a study is an important matter. This study has research questions about the perceptions of students. The researcher used a questionnaire and an interview in aims to discuss these questions. The questionnaire uses a Likert scale with a close-ended question, and then it consists of 18 questions. The questionnaire is adapted from journals by Ebrahimi et al., [11] about student perceptions of effective discussion in online forums. The questionnaire consists of affective aspects, cognitive aspects, and conative aspects. The statements have been modified by the authors as needed for the study. Then, the students fill the questionnaire in Google Form. The second is interview. The interview used semi-structure. The researchers used interviews to obtain more in-depth data from student perceptions of the forum discussion from the questionnaire results. Interviews were done by phone call, as it was impossible to hold a meeting when COVID-19 was going PSBB.

\subsection{Data Collection Technique}

This research has used the survey method as a datagathering method. In the report of Ary et al., [12], there 
are six data collection stages in the survey process. First, the researchers prepare a questionnaire that refers to the research problem and ensures it is easy to understand. Then, the researchers decide the sample. Next, the researchers distribute the questionnaire to the students by Google Form and conduct interviews with the 6 selected participants. By calling participants one by one on the phone, the researcher carried out interviews. The researcher recorded all of the interviews to collect information during the interview. The final stage is to process the data that has been obtained.

\subsection{Data Analysis Technique}

After all the respondents have answered the questionnaire, the researcher reads the responses one by one, and the researcher classifies the responses. After they have been classified, the responses are counted as a percentage. Next, the findings would be in the form of a table and addressed in the way of several categories on the blueprint questionnaire.

The next tool is the interview. As state by Miles et al., [13, p. 30], there are three ways to analyze interview data. First is data reduction. Then, the data is collected to provide the possibility to draw conclusions and take action. Last, make a conclusion from the data.

\section{FINDING AND DISCUSSION}

\subsection{Cognitive Aspect}

\subsubsection{Questionnaire Results}

The results in table 1 indicated that $70.96 \%$ students were had benefited from the use of discussion forum for their writing. Besides, $77.43 \%$ students also recognized that Schoology Discussion Forums for writing had had a good effect. In similarly, as many as $83.88 \%$ students disagreed of the SDF could not help them to improve their writing skill. Also, $80.65 \%$ of students agree that be a participant in SDF can improve writing skill. Moreover, $74.20 \%$ students agreed that read their friends' posts in SDF can help to see other views that have never been thought of before. Lastly, 87.07\% students agreed that explain the writing in SDF makes it easier to understand.

Table 1. Students' perceptions of the Schoology Discussion Forum: cognitive aspect

\begin{tabular}{|c|c|c|c|c|c|}
\hline Cognitive Aspects & $\begin{array}{l}\text { Strongly } \\
\text { Agree }\end{array}$ & Agree & Neutral & Disagree & $\begin{array}{l}\text { Strongly } \\
\text { Disagree }\end{array}$ \\
\hline $\begin{array}{l}\text { (Q3) I have benefited from the use of discussion } \\
\text { forum for my writing. }\end{array}$ & 9,67 & 61,29 & 29,04 & 0,00 & 0,00 \\
\hline $\begin{array}{l}\text { (Q8) The discussions section \& activities in } \\
\text { Schoology don't help me to improve my skill in } \\
\text { English writing. }\end{array}$ & 0,00 & 6,45 & 9,67 & 54,84 & 29,04 \\
\hline $\begin{array}{l}\text { (Q11) The use of the Schoology forum } \\
\text { discussion did not affect my writing. }\end{array}$ & 0,00 & 6,45 & 16,12 & 64,51 & 12,92 \\
\hline $\begin{array}{l}\text { (Q12) Exchanging opinions with other students } \\
\text { in the Discussion Forum helped me look at the } \\
\text { topic from a perspective that I would not have } \\
\text { considered independently. }\end{array}$ & 29,04 & 45,16 & 25,80 & 0,00 & 0,00 \\
\hline $\begin{array}{l}\text { (Q15) Participation in the Discussion Forum } \\
\text { using English helps me to improve my writing } \\
\text { skill. }\end{array}$ & 22,58 & 58,07 & 19,35 & 0,00 & 0,00 \\
\hline $\begin{array}{l}\text { (Q17) The process of writing through the topic in } \\
\text { the Discussion Forum of Schoology helped me to } \\
\text { understand them better. }\end{array}$ & 41,94 & 45,16 & 9,68 & 9,68 & 0,00 \\
\hline
\end{tabular}

\subsubsection{Interview Results}

From the interview, the researchers found some result in cognitive aspect. It could be summarized as follows:

- SDF help them to improved their writing skill, although it did not significantly.

- The students gained benefited from SDF for their writing, such as: understanding the structure of writing, drafting for outline, and how to make a good essay.

The findings from the questionnaire and interview show that most participants showed a positive attitude. The findings showed that the students get benefit from the use of the SDF for their writing. Besides, students also recognized that Schoology Discussion Forums for writing had had a good effect. It has similar result with research by Alzahrani (2017b, p. 165). 
Similarly, students said that the Schoology Forum discussion would improve their writing skills, especially if they participate directly in the Schoology Forum discussion. These results are the same as research by Akmal (2017). Next, the finding similar to the finding of Ebrahimi et al., (2017) about the SDF impacts students' thinking and makes them understand more about something.

\subsection{Affective Aspect}

\subsubsection{Questionnaire Results}

As shown table 2, $87.10 \%$ students agreed that Schoology is a user-friendly application. Then, $83.86 \%$ students agreed that they enjoyed participating in SDF.
On the other hand, $41.93 \%$ students' undecided of feeling unusual and confused using the discussion forum. Although, there are $54.83 \%$ students agreed that SDF gain their motivation to write in English. Even so, as many as $45.16 \%$ students agreed that they feel nervous when writing opinions in English in SDF. Additionally, $61.30 \%$ students' undecided the statement about interest when participant in discussion activities. Next, there are $77.41 \%$ students agreed that they interest in reading through classmates' comments in SDF. On the other hand, $41.94 \%$ students did not choose between agree and disagree of better not to use SDF in Essay Writing 1 class. However, $80.64 \%$ students would again enjoy participating in such a discussion forum.

Table 2. Students' perceptions of the Schoology Discussion Forum: affective aspect

\begin{tabular}{lccccc}
\hline \multicolumn{1}{c}{ Affective Aspects } & $\begin{array}{l}\text { Strongly } \\
\text { Agree }\end{array}$ & Agree & Neutral & Disagree & $\begin{array}{l}\text { Strongly } \\
\text { Disagree }\end{array}$ \\
\hline $\begin{array}{l}\text { (Q1) Schoology website/application is user- } \\
\text { friendly for writing class. }\end{array}$ & 22,59 & 64,51 & 12,90 & 0,00 & 0,00 \\
\hline $\begin{array}{l}\text { (Q2) I enjoyed participating in the Discussion } \\
\text { Forum of Schoology. }\end{array}$ & 19,35 & 64,51 & 9,69 & 6,45 & 0,00 \\
\hline $\begin{array}{l}\text { (Q4) I was unfamiliar with the Schoology forum } \\
\text { discussion at first. }\end{array}$ & 12,90 & 25,80 & 41,93 & 16,12 & 3,25 \\
\hline $\begin{array}{l}\text { (Q7) Discussions in Schoology increase my } \\
\text { motivation for writing in English. }\end{array}$ & 22,58 & 32,25 & 35,48 & 9,69 & 0,00 \\
\hline $\begin{array}{l}\text { (Q9) Sometimes I am not interested when } \\
\text { participating in discussion activities. }\end{array}$ & 9,69 & 19,35 & 51,61 & 19,35 & 0,00 \\
\hline $\begin{array}{l}\text { (Q10) I was interested in reading my classmates' } \\
\text { posts. }\end{array}$ & 25,80 & 51,61 & 19,35 & 3,24 & 0,00 \\
\hline $\begin{array}{l}\text { (Q14) I feel nervous using English when } \\
\text { discussing section in the Discussion Forum of } \\
\text { Schoology. }\end{array}$ & 6,45 & 38,71 & 19,35 & 29,04 & 6,45 \\
\hline $\begin{array}{l}\text { (Q16) I would have liked this course better } \\
\text { without the Discussion Forum of Schoology. }\end{array}$ & 3,22 & 19,35 & 41,94 & 29,04 & 6,45 \\
\hline $\begin{array}{l}\text { (Q18) I would enjoy participating in such a } \\
\text { discussion forum again. }\end{array}$ & 19,35 & 61,29 & 9,68 & 9,68 & 0,00 \\
\hline
\end{tabular}

\subsubsection{Interview Results}

From the interview, all of the students who interviewed by researchers stated that Schooogy is a user- friendly application among them. Even, one student thinks Schoology has a bit of a problem with scheduling task deadlines. Moreover, four students said that they did not feel like they were studying because learning carried out in online. Students also said that said they were less excited when the theme of the discussion was continually repeated. They also stated that they were nervous about using English when they were having a discussion. But, one student said he was not nervous when writing in English at SDF. In addition, students stated that they often re-read the discussion. Then, the students argue that they cannot see any real discussion in the forum. Lastly, they tell the researchers that the students will take part in the discussion again if the courses taken are under the skills to be used. The result can summarize as follows:

- Schoology is user friendly.

- The students does not feel like in class.

- The students have an interest in discussion, depending on the subject to be discussed.

- The students still nervous of using English in SDF.

- The students often re-read the discussion.

- The students did not see real discussion.

- The students will take part in discussion again, depend of the skill taught. 
The findings from the questionnaire and interview show that most participants have shown. There are positive effects on the use of Schoology discussion forum. First, students enjoy when participating in the Schoology Forum discussion. It was the same as finding the journal by [9], [11], [14]. Although at first, the students had experienced confusion and unfamiliar with Schoology. But after that, the students said that Schoology is a user-friendly application for them. That is matched with theories by Rosalina [15, p. 190]. However, students can learn the use of Schoology quickly because it looks like Facebook. It is as stated in the journal Manning et al.,[4, p. 26]. Second, the students state that the discussion can be re-read. It is similar to the statements in the theory of Ellis [16, p. 171].

Interestingly, they often read their friends' posts as well. They do it when they are stuck doing their job. It is different from the result of Ebrahimi et al.,[11]. Moreover, there was a similar finding by Yang [17, $\mathrm{p}$. 392], which they motivated when they know how to use English for discussion. The student also said they would enjoy it when they use the forum discussion for learning again. Although some students said it depends on the skills that will be teaching.
On the other hand, the result has different results by Ebrahimi et al., [11] that students are not nervous. In this study, the researchers found that students were still nervous when writing in English. Some students also said that they felt lazy when discussing because students were not used to learning from home. It is also dissimilar with Ebrahimi et al. 's (2017) research finding, which is fun and amusing. Furthermore, the students sometimes said they do not seem interested in the discussion, depending on what will be discussed. According to some students in the interview, the use of discussion is not entirely like a discussion. They feel that the discussion is only used for assignments given by the lecturer.

\subsection{Conative Aspect}

\subsubsection{Questionnaire Results}

From the table 3, the researchers can gain the information from the students. First, $67.74 \%$ students agreed that they always prepare the material themselves before joining SDF. In addition, as many as $80.65 \%$ students agreed if they did not pay attention, when they have a discussion in SDF. Lastly, there are $45.16 \%$ student students either choose between agree or disagree of apply the knowledge from the discussion into daily life.

Table 3. Students' perceptions of the Schoology Discussion Forum: conative aspect

\begin{tabular}{lcccccc}
\hline \multicolumn{1}{c}{ Conative Aspects } & $\begin{array}{l}\text { Strongly } \\
\text { Agree }\end{array}$ & Agree & Neutral & Disagree & $\begin{array}{l}\text { Strongly } \\
\text { Disagree }\end{array}$ \\
\hline $\begin{array}{l}\text { (Q5) After gaining knowledge from the } \\
\text { discussion, I apply it in my daily life. }\end{array}$ & 0,00 & 12,91 & 45,16 & 22,58 & 19,35 \\
\hline $\begin{array}{l}\text { (Q6 When I have a discussion, I did not pay close } \\
\text { attention to it. }\end{array}$ & 32,25 & 48,40 & 12,91 & 3,22 & 3,22 \\
\hline $\begin{array}{l}\text { (Q13) I always prepare the material and myself } \\
\text { before the discussion starts }\end{array}$ & 22,58 & 45,16 & 16,13 & 16,13 & 0,00 \\
\hline
\end{tabular}

\subsubsection{Interview Results}

From students' statement in interview, they state that the knowledge from SDF is not used in daily life for some of them. Nevertheless, there is a student who uses it in daily life, other words making novels in an online application. Then, the students have variation in prepare before learning. Three students always prepare the material before the discussion begins. Finally, a few of the students who were interviewed by researchers has variation in answer in pay attention to discussion. There are two students who pay careful attention to the whole discussion. But on the other hand, three students only check every few minutes of SDF. It can summarize as follows:
- The students did not use the knowledge that they gained from SDF into their daily life.

- They did not always prepare themselves before discussion began.

- Last, they also did not fully attention to discussion in SDF.

From the two findings of the interview and the questionnaire, it can conclude that the students were well prepared. It confirms the theory from Versteijlen et al., [18] that students learn the material independently. In addition, students also said prepare materials, tools for discussion and prepared for themselves before starting the discussion in the interview.

Furthermore, they stated that they always paid attention to the ongoing discussion in the forum 
discussion when they were discussing. In the interview, some participants said that they did not fully pay attention to the discussion. It is strengthening the statement Versteijlen et al., [18] about the lack of online learning. Finally, a statement that they do not apply the knowledge gained from forum discussions into their lives. Students have a reason. They have a fear of applying outside the context of the assignment. However, one student applied it in the form of story writing in an online reading application.

\section{LIMITATIONS AND FUTURE DIRECTIONS}

To avoid misunderstanding and to clarify the problem. There are limitations to this research. First, the participant is only on the students of Essay Writing 14B class on English Education of UHAMKA in Academic Year of 2020/2021. Second, this investigation is conducted to determine the students' perception of the Schoology discussion forum for writing class. Third, this research only looks for three aspects, namely: cognitive aspect, affective aspect, and conative aspect.

According to the researcher's results, the researcher had suggestions, including: For English teachers, Schoology discussion forums can support English learning, especially writing skills online and offline as a variety of learning media. Then for further authors, this study's results can be used as a reference for further research.

\section{CONCLUSIONS}

Based on the research results, it concluded from the perception of students about SDF at students in writing class. The perception aspect is divided into three parts, as follows: cognitive, affective, and conative. First, students gave positive opinions in the cognitive aspect. It is confirmed by the percentage of students' statements about getting the benefits of using the Schoology Discussion Forum as much as $80.65 \%$ agree with this statement. Although there is one student's adverse perceptions of the way assignments were collected in Schoology. In addition, there is an affective component. More negative perceptions tend to be present in this aspect. This statement can be stated from the percentage of $41.74 \%$ agreeing and $19.35 \%$ not having an opinion about feeling nervous when having discussions in English. It is because Indonesia is not familiar with the use of technology in teaching and learning. However, students also chose a good course of action, which was to take part in another forum discussion. Last, the conative aspect. Overall, these aspects have good enough perception. They were starting with learners preparing themselves and the material before the discussion begins. It can be seen in the percentage results of the statement which has $67.74 \%$ about preparing themselves for the material before starting the discussion. But sometimes, they did not fully pay attention to the discussion. Then, only some students apply the knowledge gained from the Schoology forum discussions to daily life. It can also be seen in the percentage table, where only $12.91 \%$ agree with applying the material they gain from the Schoology discussion forum in everyday life.

\section{REFERENCES}

[1] N. Kerimbayev, N. Nurym, A. Akramova, and S. Abdykarimova, "Virtual educational environment: interactive communication using LMS Moodle," Education and Information Technologies, vol. 25, no. 3, pp. 1965-1982, 2020, doi: 10.1007/s10639019-10067-5.

[2] F. Ferdianto and Dwiniasih, "Learning Management System (LMS) schoology: Why it's important and what it looks like," Journal of Physics: Conference Series, vol. 1360, no. 1, 2019, doi: 10.1088/1742-6596/1360/1/012034.

[3] Wardono and S. Mariani, "Increased mathematical literacy and HOTs through realistic learning assisted by e-schoology," Journal of Physics: Conference Series, vol. 1567, no. 3, 2020, doi: 10.1088/1742-6596/1567/3/032016.

[4] C. Manning, W. Brooks, V. Crotteau, and A. Diedrich, "Tech Tools for Teachers , By Teachers: Bridging Teachers and Students," Wisconsin English Journal, vol. 53, no. 1, pp. 2428, 2011.

[5] T. T. Schmidt, "Subjectivities- in-Process:" Writing Race and the Online Discussion Board By," Sereal Untuk, vol. 51, no. 1, p. 51, 2011.

[6] Y. Chen and L. B. Hoshower, "Student evaluation of teaching effectiveness: An assessment of student perception and motivation," Assessment and Evaluation in Higher Education, vol. 28, no. 1, pp. 71-88, 2003, doi: 10.1080/02602930301683.

[7] J. Jose and M. J. Z. Abidin, "A Pedagogical Perspective on Promoting English as a Foreign Language Writing through Online Forum Discussions," English Language Teaching, vol. 9, no. 2, p. 84, 2016, doi: 10.5539/elt.v9n2p84.

[8] J. Patel and A. Aghayere, "Students' perspective on the impact of a web-based discussion forum on student learning," Proceedings - Frontiers in Education Conference, FIE, pp. 26-31, 2006, doi: 10.1109/FIE.2006.322600. 
[9] M. G. Alzahrani, "Student Satisfaction with Using Online Discussion Forums at Saudi Universities," World Journal of Education, vol. 7, no. 2, p. 1, 2017, doi: 10.5430/wje.v7n2p1.

[11] A. Ebrahimi, E. Faghih, and M. DabirMoghaddam, "Student perceptions of effective discussion in online forums: A case study of preservice teachers," Innovations in Education and Teaching International, vol. 54, no. 5, pp. 467475, 2017, doi: 10.1080/14703297.2016.1143858.

[12] D. Ary, L. C. Jacobs, and C. Sorensen, Introduction to Research in Education. 2010.

[13] M. B. Miles, A. M. Huberman, and J. Saldaña, Qualitative Data Analysis. SAGE Publicattionss, Inc., 2014.

[14] A. Muhtia, Suparno, and Sumardi, "Blended Learning Using Schoology As an Online," 2nd English Language and Literature International Conference (ELLiC), vol. 2, pp. 171-175, 2018.

[15] M. Rosalina, "Analysis The Use of Schoology ELearning Towards Students' Learning Motivation Enhancement in STKIP Surya," Indonesian
[10] M. G. Alzahrani, "The effect of using online discussion forums on students' learning," Turkish Online Journal of Educational Technology, vol. 16, no. 1, pp. 164-176, 2017.

Journal of Science and Education, vol. 2, no. 1, p. 89, 2018, doi: 10.31002/ijose.v2i1.614.

[16] A. Ellis, "Student-centered Collaborative Learning via Face-to-face and Asynchronous Online Communication: What's the Difference?," Proceedings 18th ASCILITE Conference Melbourne, pp. 169-178, 2001.

[17] Q. Yang, "Students Motivation in Asynchronous Online Discussions with MOOC Mode," American Journal of Educational Research, vol. 2, no. 5, pp. 325-330, 2014, doi: 10.12691/education-2-5-13.

[18] M. Versteijlen, F. Perez Salgado, M. Janssen Groesbeek, and A. Counotte, "Pros and cons of online education as a measure to reduce carbon emissions in higher education in the Netherlands," Current Opinion in Environmental Sustainability, vol. 28, pp. 80-89, 2017, doi: 10.1016/j.cosust.2017.09.004 